\title{
Membangun Efektifitas Dakwah Dengan Memahami Psikologi Mad'u
}

\section{Ujang Mahadi}

\author{
IAIN Bengkulu \\ Muhadi4kdzhnh@yahoo.com
}

\begin{abstract}
The Indonesian nation is currently suffering from a multi-dimensional crisis, a crisis of trust (trust), a moral, economic, socio-political and cultural crisis. This nation is also experiencing a crisis of human values, the drying up of spiritual values, the occurrence of social and religious social changes, including traditional changes to the modern. Therefore, the da'wah movement has become an indispensable necessity and should not be delayed to face the challenges and multi-dimensional crisis. Da'wa activities will always be in direct contact with the community and dealing with various realities of the problems of buman life, so preaching must be planned, has a clear concept, measurable, organized and can even be evaluated. Da'wah must appear actual, factual and contextual. Da'wah should be delivered in a way that is good, wise, full of wisdom, attentive, seriousness, sincere intentions, while still paying attention to your psychology so that the moral messages and noble values of religious teachings conveyed in dakwah can be accepted and digested.
\end{abstract}

Keywords: Effectiveness, Da'wah, and Psychology of Audiens

\begin{abstract}
Abstrak
Bangsa Indonesia saat ini tengah terpuruk dalam krisis multi dimensional, krisis kepercayaan (amanah), krisis moral, ekonomi, sosial politik dan budaya. Bangsa ini pun sedang mengalami krisis nilai-nilai insani, keringnya nilai-nilai spiritual, terjadinya perubahan sosial dan sosial keagamaan, termasuk, perubahan tradisional kepada modern. Oleh karena itu, gerakan dakwah sudah menjadi keharusan yang sangat dibutubkan dan tidak boleh ditunda-tunda untuk menghadapi tantangan dan krisis multi dimensional itu. Aktivitas dakwah akan senantiasa bersentuban langsung dengan masyarakat dan berhadapan dengan berbagai realitas persoalan kehidupan manusia, maka dakwah harus dilakukan secara terencana, memiliki konsep yang jelas, terukur, terorganisir dan bahkan dapat dievaluasi. Dakwah harus tampil secara aktual, faktual dan kontekstual. Dakwah hendaklah disampaikan dengan cara yang baik, bijak, penub bikmah, penub perhatian, keseriusan, niat yang ikhlas, dengan tetap memperhatikan psikologi mad'u agar pesan moral dan nilai-nilai lubur ajaran agama yang disampaikan dalam dakwah dapat diterima dan dicerna.
\end{abstract}

Kata Kunci: Aktifitas, Dakwah, Psikologi Mad'u 


\section{A. Pendahuluan}

Kondisi umat saat ini sedang dilanda keprihatinan hidup yang mencemaskan. Jika tidak segera ditangani, diberikan obat penawar dan dicarikan solusi terbaik maka dapat merusak dan menghancurkan nilai-nilai moral masyarakat. Melakukan dakwah Islam secara efektif, efisien dan berkesinambungan dengan cara-cara yang bisa diterima oleh semua kalangan penting dilakukan sebagai penawar dan upaya preventif.

Kemajuan ilmu pengetahuan dan teknologi membawa perubahan yang sangat besar dalam berbagai segi tatanan kehidupan manusia, mulai dari cara berpikir, bersikap, dan bertingkah laku. Tetapi dalam dimensi lain kemajuan ilmu pengetahuan dan teknologi telah menimbulkan dampak yang dapat mengancam kehidupan manusia. ${ }^{1}$ Modernisasi dan globalisasi di satu sisi membawa banyak manfaat bagi kehidupan manusia, tetapi disisi lain, bagi masyarakat yang secara psikologis belum siap menghadapi perubahan, modernisasi dapat menciptakan kesulitan psikologis, ${ }^{2}$ seperti ditegaskan Faridl,3 "napas kehidupan di tengah-tengah arus modernism diwarnai dengan berbagai kegelisahan moral, sosial, maupun spiritual".

Kemajuan dan perkembangan kehidupan yang dihasilkan manusia di bidang ilmu pengetahuan, teknologi informasi dan komunikasi di zaman modern sekarang ini, secara positif membantu dan memberikan kemudahan bagi manusia, seperti mudahnya mengakses dan menyampaikan informasi, lancarnya transportasi dan komunikasi, cepatnya melakukan berbagai aktivitas perekonomian, dan lain sebagainya. Namun demikan, tidak dapat dipungkiri bahwa cepatnya arus perubahan yang terjadi, juga membawa dampak negatif yang melahirkan berbagai persoalan dalam kehidupan, salah satu diantaranya adalah merosotnya nilai-nilai moralitas manusia.

Di era modern ini manusia mengalami krisis nilai-nilai insani, karena manusia tidak sanggup mengantisipasi kemajuan ilmu pengetahuan dan teknologi yang menyebabkan timbulnya perubahan-perubahan sosial dan sosial keagamaan, termasuk perubahan tradisional kepada modern. ${ }^{4}$ Bangsa Indonesia saat ini tengah terpuruk dalam krisis multi dimensional; krisis kepercayaan (amanah), krisis moral, ekonomi, sosial politik dan budaya. Oleh karena itu membangun aktivitas dakwah yang sanggup menghadapi tantangan merupakan suatu keharusan yang tidak boleh ditunda-tunda. ${ }^{5}$

1 M. Jakfar Puteh, "Dakwah di Era Globalisasi: Strategi Menghadapi Perubahan Sosial", Cetakan Ketiga, (Yogyakarta: Ak. Group, 2006), 131.

2 Ahmad Mubarok, "Psikologi Dakwah", Cetakan keempat, Jakarta: Pustaka Firdaus, 2008), 47.

3 Miftah Faridl, "Cahaya Ukbuwah", (Bandung: Ikhtiar Publishing, 2005), 71.

${ }^{4}$ M. Jakfar Puteh, "Dakwah di Era Globalisasi: Strategi Menghadapi Perubahan Sosial". Cetakan Ketiga, (Yogyakarta: Ak. Group, 2006), 131.

${ }^{5}$ Nana Rukmana D.W., "Masjid dan Dakwab: Merencanakan, Membangun dan Mengelola Masjid Mengemas Sbstansi Dakwah Upaya Pemecaban Krisis Moral dan Spiritual", Jakarta: Almawardi Prima, . 2002), 169. 
Kecenderungan pola pikir masyarakat modern saat ini, juga banyak dipengaruhi oleh gaya hidup dan pemikiran sekularisme yang mengakibatkan pergeseran pemahaman dan cara pandang manusia, dari yang bersifat kolektif ke individualistik, dari yang bernuansa agamis ke materialistik. Kecenderungan ini tentu saja mempengaruhi pola hidup keagamaan masyarakat modern. ${ }^{6}$

Perlu ditegaskan, upaya yang harus dilakukan dalam mengimbangi kemajuan zaman dan menjaga umat dari kerusakan moral adalah dengan melakukan dakwah terus-menerus dan tanpa mengenal lelah. Dakwah merupakan proses mengubah seseorang maupun masyarakat (baik pemikiran, perasaan, perilaku) dari kondisi yang buruk kepada kondisi yang lebih baik, lebih terhormat, lebih bermartabat dan lebih sejahtera. Dakwah merupakan suatu aktivitas mengajak dan menyampaikan ajaran Islam yang dilakukan secara sadar, sengaja dan terencana dengan menggunakan berbagai cara/metode dengan tujuan memberikan pemahaman keagamaan, mengubah pandangan dan cara hidup, sikap bathin dan perilaku umat agar mau mengamalkan ajaran Islam sesuai dengan tuntunan syar'iat untuk mencari ridha Allah SWT agar memperoleh kebahagiaan hidup di dunia dan di akhirat.

\section{B. Pembahasan}

\section{Dakwah Membangun Peradaban Manusia}

Kecenderungan pola pikir masyarakat modern saat ini banyak dipengaruhi oleh gaya hidup dan pemikiran sekuler yang mengakibatkan pergeseran pemahaman dan cara pandang manusia, dari yang bersifat kolektif ke individualistik, dari yang bernuansa agamis ke materialistik. ${ }^{7}$ Kondisi masyarakat sekarang ternyata jauh dari nilai-nilai Islam. Moral, akhlak, aqidah masyarakat tidak sesuai dengan Islam. Masyarakat sedang membutuhkan banyak sosok da'i yang mampu membawa mereka lebih mengenal Islam. ${ }^{8}$

Menghadapi arus deras perkembangan kehidupan manusia, baik secara positif berupa kemajuan dan kemoderenan atau secara negatif berupa kebangkrutan nilai-nilai moralitas, gerakan dakwah dituntut untuk terus melahirkan jurus-jurus baru yang segar. ${ }^{9}$ Dakwah harus dikemas dengan cara yang tepat dan pas. Dakwah harus tampil secara aktual, faktual dan kontekstual. Aktual dalam arti memecahkan masalah kekinian dan hangat di tengah masyarakat. Faktual dalam arti kongkrit dan nyata,

'Samsul Munir Amin, "Rekontruksi Pemikiran Dakwah Islam", Jakarta: Amzah, 2008), 35.

${ }^{7}$ Ibid.

8 Melalui: < http://kabarnetwordpress. com/2010/02/26/peran-mahasiswasebagai-dai-ditengah-umat/ > [7/10/2011].

9 Jurnal Ilmu Dakwah, "Menyegarkan Paradigma Dakwah Islam", (Fakultas Dakwah UIN Sunan Gunung Djati Bandung, Vol. 3 No. 6/Juli-Desember 2005), hal. v. 
serta kontekstual dalam arti relevan dan menyangkut problema yang sedang dihadapi masyarakat. ${ }^{10}$

Di era globalisasi dan alam keterbukaan seperti sekarang ini, aktivitas dakwah masih tetap dan sangat diperlukan baik sebagai pemacu dalam mempercepat pembangunan bangsa dan sekaligus berfungsi sebagai perisai untuk menangkal ekses negatif yang diakibatkan dari globalisasi teknologi dan informasi. Dakwah Islam yang dilakukan memiliki fungsi startegis, selain memberikan pencerahan spiritual dengan penanaman nilainilai religius dan moralitas, juga dapat berfungsi dalam pemberdayaan masyarakat dan sebagai pemberi solusi terhadap persoalan yang dihadapi masyarakat umat manusia.

Enjang dan Aliyudin, ${ }^{11}$ mengatakan fungsi dakwah Islam sebagai solusi berbagai problema psikologis, sosiologis, ekonomis, dan politis dalam kehidupan individu, kelompok dan masyarakat yang semakin kompleks memasuki millennium ketiga. Berkenaan dengan fungsi dakwah, Attarmizi dan Kalam, ${ }^{12}$ menegaskan "fungsi dakwah dalam pemberdayaan umat berkenaan dengan bagaimana menyosialisasikan nilai-nilai ajaran Islam dalam membangun proses perubahan masyarakat. Karena, dakwah itu sendiri bermakna mengubah tatanan kehidupan ke arah yang lebih baik atau maslahat. Perubahan ini bisa berlangsung apabila dilakukan gerakan penyadaran terhadap masyarakat sebagai suatu proses pemberdayaan umat. Dalam hal ini dakwah harus memiliki fungsi solusi bagi persoalanpersoalan yang ada di tengah-tengah masyarakat. Fungsi ini dilakukan dengan tidak menjadikan umat sebagai objek perubahan, tetapi sebagai subjek perubahan yang harus berperan aktif'.

Dakwah merupakan proses penyelamatan umat manusia dari berbagai persoalan yang merugikan kehidupannya, dan sebagai kerja dan karya besar manusia - baik secara individual maupun sosial - yang dipersembahkan untuk Tuhan dan sesamanya, yaitu dalam rangka menegakkan keadilan, meningkatkan kesejahteraan, menyuburkan persamaan, dan mencapai kebahagiaan atas dasar ridha Allah SWT. ${ }^{13}$

Tujuan jangka pendek kegiatan dakwah adalah untuk memberikan pemahaman tentang Islam kepada masyarakat sehingga akan terhindar dari sikap dan perbuatan munkar dan jahat. Adapun tujuan jangka panjang adalah untuk mengadakan perubahan sikap masyarakat berupa perilaku yang tidak terpuji dan menimbulkan kemudharatan serta mengganggu

${ }^{10}$ Yusuf dalam Munzier Suparta dan Harjani Hefni (ed.), "Metode Dakwab". Cetakan ke-2. (Jakarta: Kencana, 2006). 9.

${ }^{11}$ Enjang dan Aliyudin, "Dasar-dasar Ilmu Dakwah", (Bandung: Widya Padjadjaran, 2009), 175

12 Yoga Ad. Attarmizi dan M. Yajid Kalam, "KH. Moh. Ilyas Rubiat: Ajengan Santun dari Cipasung”, (Bandung: Remaja Rosdakarya, 1999), 98.

${ }^{13}$ Enjang dan Aliyudin, "Dasar-dasar Imu Dakwah", (Bandung: Widya Padjadjaran, 2009), 14. 
ketentraman masyarakat. ${ }^{14}$ Aktivitas dakwah pada dasarnya bertujuan untuk menjadikan manusia menuju ke arah yang lebih baik dan membentuk manusia yang berperadaban. ${ }^{15}$ Izmuddin, ${ }^{16}$ mengatakan "tujuan dakwah adalah agar manusia ke luar dari lembah kegelapan menuju cahaya yang terang dan membawa mereka kepada kebenaran sehingga mereka selamat dari api neraka dan siksaan Allah, dakwah juga bertujuan agar seorang kafir ke luar dari kekufurannya menuju jalan petunjuk, dakwah juga bertujuan agar orang yang bodoh ke luar dari kebodohannya menuju kepada ilmu pengetahuan, dan agar orang yang bermaksiat ke luar dari kemaksiatannya menuju ketaatan kepada Allah”.

Tujuan dakwah adalah mengubah suatu keadaan masyarakat dari yang kurang baik menjadi lebih baik dalam berbagai hal dengan ukuran agama. ${ }^{17}$ Menurut Amin, ${ }^{18}$ berdakwah adalah kewajiban individual atau farddhu 'ain bagi setiap orang Islam yang mukallaf. Tentu saja kewajiban ini sesuai dengan kemampuan masing-masing.

Aktivitas dakwah akan senantiasa bersentuhan langsung dengan masyarakat dan berhadapan dengan berbagai realitas persoalan kehidupan manusia, maka dakwah harus dilakukan secara terencana, memiliki konsep yang jelas, terukur, terorganisir dan bahkan dapat dievaluasi. Dakwah merupakan kewajiban dan tanggungjawab setiap muslim, dan kegiatan ini telah berlangsung sejak masa Rasulullah saw dan para sahabatnya yang kemudian dilanjutkan oleh generasi sesudahnya. Kegiatan dakwah harus dilakukan terus menerus dan berkesinambungan, karena tugas untuk menyampaikan dakwah adalah perintah dari wahyu (al-Qur'an) dan Sunnah Rasul (hadits). Dalam al-Qur'an surat Ali Imran ayat: 110 ditegaskan:

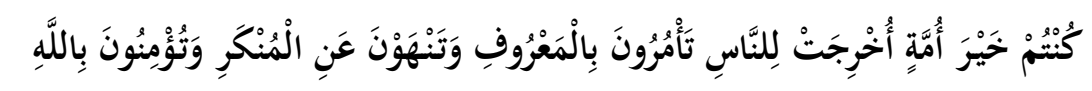

"Kamu adalah umat yang terbaik yang dilabirkan untuk manusia, menyurub kepada yang makruf, dan mencegah dari yang munkar, dan beriman kepada Allab” (QS. Ali Imran: 110).

14 M. Bahri Ghazali, "Dakwah Komunikatif: Membangun Kerangka Dasar Ilmu Komunikasi Dakwah", (Jakarta: Pedoman Ilmu Jaya, 1997), 7.

15 Zainudin, "Dakwah Transformative (Studi tentang Amar Makmur Nabi Munkar dalam Surat Ali Imran Ayat 110)", (dalam Jurnal PMI. Vol. IV. Nomor 2, Maret 2007), 167.

16 Iiz Izmuddin, "Hukum dan Etika Dakwah", (dalam Al-Hurriyah: Jurnal Hukum Islam P3M STAIN Sjech Djamil Jambek-Bukit Tinggi, V01. 10, No. 1, Januari - Juni 2009), 75.

${ }^{17}$ Rosyidi, "Pemberdayaan Masyarakat Melalui Dakwah Aktif Partisipatif", (dalam Jurnal Pengembangan Masyarakat Islam "Komunitas", Lembaga Pengabdian kepada Masyarakat (LPM) IAIN Raden Intan Bandar Lampung, Vol. 27, No. 1, Juni 2009), 3.

18 Samsul Munir Amin, "Rekontruksi Pemikiran Dakwah Islam", Jakarta: Amzah, 2008), 61. 
Rasulullah saw dalam hadisnya menyatakan:

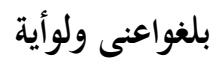

"Sampaikan olehmu (apa yang kamu terima) dariku walaupun satu ayat".

Untuk mencapai tujuan sebagaimana diisyaratkan al-Qur'an dan hadits di atas, sudah seharusnya umat Islam (khususnya para da’i) merumuskan strategi dakwah yang membumi dalam konteks kekinian dan kedisinian yang dapat menjawab tantangan serta menyelesaikan persoalan yang dihadapi umat. Setiap pelaku dakwah (da’i) hendaklah membekali diri dengan kemampuan dan penguasaan pengetahuan agama secara mendalam, memiliki ilmu pengetahuan dan teknologi serta berakhlakul karimah. Bagi pelaku dakwah, juga penting membekali diri dengan "ilmu komunikasi” terutama yang berkaitan dengan "prinsip-prinsip komunikasi efektif" dan budaya lokal - yakni budaya tempat dimana dakwah dilaksanakan. Dengan bekal tersebut, pesan dakwah yang disampaikan akan mudah diterima dan dipahami oleh jama'ah/masyarakat dan tujuan dakwah dapat tercapai.

Memasuki era kontemporer, untuk meningkatkan kembali energinya, praktik dakwah harus mampu menampakkan wajah dengan nuansa yang lebih atraktif, menyentuh, aktual, solutif dan komunikatif. Prasyarat utamanya tentu para pelaku dakwah menjadi dituntut untuk memiliki kemampuan, wawasan yang luas, daya kreativitas dan kejeniusan yang tinggi. ${ }^{19}$ Enjang dan Aliyudin, ${ }^{20}$ mengatakan "dakwah dalam praktiknya merupakan kegiatan yang sudah cukup tua, yaitu sejak adanya tugas dan fungsi yang harus diemban oleh manusia dibelantara kehidupan dunia ini. Oleh sebab itu, eksistensi dakwah tidak dapat dipungkiri oleh siapa pun, karena kegiatan dakwah sebagai proses penyelamatan umat manusia dari berbagai persoalan yang merugikan kehidupannya, merupakan bagian dari tugas dan fungsi manusia yang sudah direncanakan sejak awal penciptaan manusia sebagai khalifah fi al-ardh".

Secara makro, eksistensi dakwah Islam senantiasa bersentuhan dan bergelut dengan realitas yang mengitarinya. ${ }^{21}$ Ilaihi, ${ }^{22}$ mengatakan "dakwah memiliki peranan yang strategis dan signifikan dalam membentuk perdamaian global. Betapa tidak, di era modern, ketika kehidupan manusia dan masalah-masalahnya begitu kompleks, peran dakwah sangat

19 Lihat dalam "Editorial" Jurnal Ilmu Dakwah. Fakultas Dakwah dan Komunikasi UIN Sunan Gunung Jati Bandung. Vol. 4. No. 11. Januari - Juni 2008. Halaman 7.

${ }^{20}$ Enjang dan Aliyudin, "Dasar-dasar Ilmu Dakwah", (Bandung: Widya Padjadjaran, 2009), 1.

${ }^{21}$ Samsul Munir Amin, "Rekontruksi Pemikiran Dakwah Islam", Jakarta: Amzah, 2008), 16.

22 Wahyu Ilaihi, "Dakwah Sebagai Solusi Perdamaian Global", (dalam Congress Proceeding Fak. Dakwah IAIN Sunan Ampel Surabaya bekerjasama dengan APDI/Asosiasi Profesi Dakwah Islam Indonesia, 2009), 300. 
dibutuhkan untuk memberi topangan nilai. Dakwah tidak lagi hanya berkutat pada masalah-masalah spiritual dan eskatologis, tetapi juga harus beranjak ke aspek-aspek riil masyarakat pemeluknya. Dengan menanamkan nilai-nilai moral sehingga manusia memiliki kemampuan tinggi untuk mengatasi masalah-masalahnya dengan tanpa merusak harmoni dengan lingkungannya. Dengan nilai-nilai moral agama, manusia memiliki kecakapan dan ketajaman membaca tanda-tanda zaman berikut kemampuan menciptakan seperangkat nilai untuk melestarikannya, seperti hukum dan sejumlah peraturan".

Salah satu dari tujuan dakwah adalah untuk memberikan kesadaran, mengubah perilaku, dan mengajak manusia ke arah yang lebih baik, lebih mulia, lebih terpuji, lebih beradab, lebih terhormat, dan lebih bermartabat dengan menjalankan ajaran agama secara benar dan totalitas. Dakwah juga harus dapat memberikan solusi terhadap persoalan yang dihadapi masyarakat umat manusia, mengingat eksistensi dakwah senantiasa bersentuhan langsung dengan masyarakat dimana dakwah itu dilakukan.

Dengan demikian, persoalan yang dihadapi masyarakat juga merupakan persoalan dakwah yang membutuhkan perhatian dan penyelesaian. Melalui komunikasi dakwah yang efektif dengan orientasi problem solving maka dakwah akan mampu memerankan fungsinya sebagai salah satu alat bagi perubahan masyarakat (social change). Untuk melakukan perubahan, pembangunan dan perkembangan masyarakat, dakwah menjadi salah satu unsur penting yang harus dilibatkan, terlebih pada masyarakat yang mayoritas beragama Islam.

\section{Esensi Psikologi dalam Aktivitas Dakwah}

Kegiatan dakwah adalah kegiatan komunikasi, dan komunikasi menyebabkan terjadinya interaksi sosial. Agar dakwah bersifat komunikatif seorang da'i memerlukan pengetahuan tentang gejala-gejala sosial atau tingkah laku manusia dalam lingkungan sosio-kulturnya dan seberapa jauh keyakinan agama mempengaruhi tingkah lakunya. oleh karena itu, dakwah sebagai ilmu bersinggungan dengan beberapa disiplin ilmu, antara lain, komunikasi, sosiologi, psikologi sosial, psikologi agama di samping ilmuilmu keagamaan itu sendiri". ${ }^{23}$

Kajian untuk memahami aspek mental dan proses perilaku manusia terkait dengan proses dakwah, dalam sistem dakwah disebut psikologi dakwah, yaitu sebuah kajian yang membahas tentang aspek

23 Ahmad Mubarok, "Psikologi Dakwah", Cetakan keempat, Jakarta: Pustaka Firdaus, 2008), 20. 
mental dan perilaku manusia dalam proses dakwah, khususnya terkait dengan psikologi da'i, psikologi mad'u dan psikologi maudhu. ${ }^{24}$

Psikologi dakwah adalah ilmu bantu yang sangat diperlukan dalam menyampaikan pesan kebenaran kepada masyarakat. Manusia adalah makhluk yang memiliki keunikan psikologis, sehingga persepsi manusia bisa berbeda-beda terhadap objek yang sama. Keberhasilan suatu dakwah tidak hanya ditentukan oleh nilai pesan yang disampaikan, tetapi juga ditentukan oleh bagaimana persepsi masyarakat mad'u terhadap pesan dakwah itu. Psikologi dakwah antara lain berusaha menguak suasana batin dari manusia yang menjadi objek dakwah sehingga dengan itu dakwah bisa secara persuasif. Dakwah persuasif adalah proses mengajak atau mempengaruhi mad'u mengikuti ajaran da'i, tetapi ia merasa sedang melakukan sesuatu atas kehendak sendiri. ${ }^{25}$

Pada hakikatnya psikologi dakwah sebagai ilmu pengetahuan bertugas mempelajari/membahas tentang gejala-gejala hidup kejiwaan, baik dari da'i maupun mad'u yang terlibat dalam proses kegiatan dakwah. Dengan memperhatikan faktor-faktor perkembangan psikologis beserta ciri-cirinya, maka pesan dakwah yang disampaikan oleh juru dakwah akan dapat meresap dan diterima dalam pribadi sasarannya dan kemudian diamalkannya kepada perasaan yang tulus tanpa adanya ganjalan karena hal tersebut dapat menyentuh dan memuaskan kehidupan rohaninya. Disinilah letak titik berat strategi-strategi dakwah yang sebenarnya yaitu menerima pesan dakwah dengan ikhlas sekaligus mempraktikkannya. ${ }^{26}$

Tujuan psikologi dakwah adalah membantu dan memberikan pendangan kepada para da'i tentang pola dan tingkah laku para mad'u dan hal-hal yang mempengaruhi tingkah laku tersebut yang berkaitan dengan aspek kejiwaan (psikis) sehingga mempermudah para da'i untuk mengajak mereka kepada apa yang dikehendaki dalam ajaran Islam. ${ }^{27}$ Enjang dan Aliyudin, ${ }^{28}$ mengatakan bahwa kajian psikologi dakwah bertujuan memberikan pandangan tentang aspek: “Psikologi da'i, yang menjadi subjek atau pelaku dakwah.

Kajian psikologi da'i berkaitan dengan aspek kognitif, afektif dan psikomotorik, serta kepribadian da'i. Psikologi pesan, kajiannnya terkait dengan pengelolaan dan penyampaian pesan yang dapat meningkatkan dan

24 Enjang AS., "Smart Dakwah: Proses Dakwah Sesuai dengan Aspek Psikologi Mad'u", (dalam Jurnal Ilmu Dakwah: Academic Journal for Homiletic Studies. Fakultas Dakwah UIN Sunan Gunung Djati Bandung, Vol. 4 No. 12/Juni-Desember 2008), 258.

25 Pendapat A. Malik Fajar dalam Ahmad Mubarok, "Psikologi Dakwah", Cetakan keempat, (Jakarta: Pustaka Firdaus, 2008), 5.

26 Melalui: < http://makalah-ibnu.blogspot.com/2008/10/peran-psikologi-dalamproses-dakwah.html $>$ [04/10/2013].

27 Melalui: < http://ishthesyndicate.blogspot.com/2013/06/psikologi-dakwah$\underline{\text { antar-budaya.html }}>[04 / 10 / 2013]$.

28 Enjang dan Aliyudin, "Dasar-dasar Ilmu Dakwab", (Bandung: Widya Padjadjaran, 2009), 150-151. 
mengendalikan pemahaman, perasaan, serta dimungkinkannya dilakukan perubahan sikap mental dan perilaku sasaran dakwah (mad'u) sesuai dengan pola kehidupan yang dikehendaki oleh ajaran agama. Sedangkan psikologi mad'u, mengkaji tentang konsepsi manusia sebagai sasaran dakwah serta faktor-faktor yang mempengaruhi pemahaman, perasaan, sikap, motif dan perilaku keberagamaan mad'u. dengan demikian, diantara fungsi psikologi dakwah untuk melakukan: 1) deskripsi atau penjelasan secara sistematis; 2) prediksi (meramalkan); 3) kontrol (mengendalikan); dan 4) development dengan pola (pattern) kehidupan yang dikehendaki oleh ajaran Islam. Psikologi dakwah juga berfungsi untuk dijadikan sebagai landasan dan pedoman dalam pengembangan metodologi dakwah, karena sebuah metode dakwah akan dapat digunakan secara efektif dalam penerapannya apabila didasarkan pada kondisi objektif sasaran dakwah".

Setidaknya ada lima ciri dakwah yang efektif dari sudut psikologi dakwah, yaitu:

1) Jika dakwah dapat memberikan pengertian kepada masyarakat (mad'u) tentang apa yang didakwahkan.

2) Jika masyarakat (mad'u) merasa terhibur oleh dakwah yang diterima.

3) Jika dakwah berhasil meningkatkan hubungan baik antara da'i dan masyarakatnya.

4) Jika dakwah dapat mengubah sikap masyarakat mad'u.

5) Jika dakwah berhasil memancing respon masyarakat berupa tindakan. ${ }^{29}$

Dengan demikian jelas bahwa profesi da'i sangat penting mengerti dan memahami "psikologi dakwah", mengingat psikologi dakwah merupakan ilmu bantu yang sangat diperlukan untuk mengetahui keunikan psikologis jama'ah/khalayak. Pentingnya mengerti dan memahami "psikologi dakwah" mengingat persepsi manusia/masyarakat jama'ah sangat beragam dan berbeda-beda. Dengan mengerti dan memahami "psikologi dakwah", da'i dapat memprediksi suasana batin, aspek mental dan proses perilaku jama'ah/khalayak yang menjadi objek dakwah, sehingga pesan dakwah dapat dikemas dan disampaikan secara efektif.

Dakwah hendaklah disampaikan dengan cara yang baik, bijak, penuh hikmah, penuh perhatian, keseriusan, niat yang ikhlas, dengan tetap memperhatikan psikologi mad'u agar pesan moral dan nilai-nilai luhur ajaran agama yang disampaikan dalam dakwah dapat diterima dan dicerna. Dakwah akan sampai kepada jama'ah manakala penyampaian materi dakwah dikemas dengan seni dan teknik berkomunikasi yang cerdas. Da’i sejatinya adalah seorang komunikolog yang membawa pesan-pesan Ilahiah untuk disampaikan kepada umat (jama'ah). Pemahaman dan pengetahuan

29 Pernyataan Mubarok dalam Faizah dan Lalu Muchsin Effendi, "Psikologi Dakwah". Jakarta: Kencana, 2006), 15. 
psikologi dan ilmu komunikasi bagi seorang da’i tentu menjadi sesuatu yang penting dan mutlak.

Seni dan kemahiran mengolah materi dakwah yang akan disajikan kepada jama'ah terdapat dalam ilmu komunikasi. Oleh karenanya, semakin baik seorang juru dakwah (da`) menguasi psikologi dan memahami ilmu komunikasi, maka akan semakin baik dan menarik pula materi dakwah yang disampaikan.

\section{Strategi Dakwah Pada Masyarakat Beda Budaya}

Keanekaragaman budaya manusia merupakan keniscayaan yang tidak dapat dielakkan, karena manusia tidak berdiri sendiri, terutama pada kehidupan yang kontemporer dan kompleks seperti dewasa ini. Menghindari fanatisme dan etnosentrisme yang berlebihan adalah hal yang penting, sebab kedua hal tersebut dapat menyebabkan perpecahan di antara manusia. ${ }^{30}$ Perbedaan budaya antara satu daerah dengan daerah lainnya acapkali sering menimbulkan perdebatan bahkan hingga menimbulkan pertumpahan darah. ${ }^{31}$

Budaya adalah suatu cara hidup yang berkembang dan dimiliki bersama oleh sebuah kelompok orang dan diwariskan dari generasi ke generasi. Budaya terbentuk dari banyak unsur yang rumit, termasuk sistem agama dan politik, adat istiadat, bahasa, perkakas, pakaian, bangunan, dan karya seni. ${ }^{32}$ Budaya-budaya yang berbeda memiliki sistem nilai yang berbeda, dan karenanya ikut menentukan tujuan hidup yang berbeda. ${ }^{33}$

Upaya pendekatan dakwah dengan mempertimbangkan dan mengayomi budaya masyarakat tertentu yang berpijak pada nilai-nilai universal kemanusiaan menjadi sebuah tuntutan. Kita sadari bahwa setiap negara mempunyai adat dan tradisi yang tidak sama, sehingga dengan pendekatan budaya, Islam akan mudah diperkenalkan dan diterima, tentu saja dengan tidak melecehkan apalagi menghilangkan budaya masyarakat setempat.

Suparta dan Hefni, ${ }^{34}$ menyatakan, dalam menghadapi mad'u yang beragam tingkat pendidikan, strata sosial, dan latar belakang budaya, para da’i memerlukan hikmah, sehingga ajaran Islam mampu memasuki ruang

${ }^{30}$ Baharudin Ali, "Prinsip-prinsip Dakwah Antarbudaya", (dalam Jurnal Tabligh: Media Pengkajian Dakwah dan Komunikasi Islam, Fakultas Dakwah dan Komunikasi UIN Alauddin Makassar, Edisi XXV/Juni 2012), 1-2.

31 Melalui: < http://ishthesyndicate.blogspot.com/2013/06/psikologi-dakwahantar-budava. $h t m l>[04 / 10 / 2013]$.

32 Melalui: < http://id.wikipedia.org/wiki/Budaya $>$ [27/09/2011].

${ }^{33}$ Baharudin Ali, "Prinsip-prinsip Dakwah Antarbudaya", (dalam Jurnal Tabligh: Media Pengkajian Dakwah dan Komunikasi Islam, Fakultas Dakwah dan Komunikasi UIN Alauddin Makassar, Edisi XXV/Juni 2012), 3.

34 Munzier Suparta dan Harjani Hefni (ed.), "Metode Dakwah", Cetakan ke-2, (Jakarta: Kencana, 2006), 11. 
hati para mad'u dengan tepat. Oleh karena itu, para da'i dituntut untuk mampu mengerti dan memahami sekaligus memanfaatkan latarbelakangnya, sehingga ide-ide yang diterima dirasakan sebagai sesuatu yang menyentuh dan menyejukkan kalbunya.

Dalam aktivitas dakwah, da'i (subjek dakwah) akan mendapat kesulitan dan hambatan apabila bersikap etnosentrik dan tidak berusaha untuk memahami nilai-nilai dan sistem budaya mad'u (sasaran dakwah). oleh karena itu, seorang da'i mestinya memperoleh gambaran pemahaman, aspirasi, perasaan, dan masalah yang dihadapi mad'u. Dengan begitu seorang da'i menjadi arif terhadap budaya mad'u-nya, karena salah satu prinsip dalam berdakwah adalah mengedepankan amar ma'ruf dan nabi munkar. ${ }^{35}$

Aripudin dan Sambas, ${ }^{36}$ menegaskan, bahwa prinsip dakwah antarbudaya adalah acuan prediktif kebenaran yang menjadi dasar berpikir dan bertindak merealisasikan bidang dakwah yang mempertimbangkan aspek budaya dan keragamannya ketika berinteraksi dengan mad'u dalam rentang ruang dan waktu sesuai perkembangan masyarakat. menurut Amin, ${ }^{37}$ untuk mencapai keberhasilan dakwah Islam secara maksimal, maka diperlukan berbagai faktor penunjang, diantaranya adalah strategi dakwah yang tepat, sehingga dakwah Islam mengena sasaran.

Perlu disadari oleh da'i bahwa kegiatan dakwah tidak berada dalam ruangan yang hampa, tapi sudah berisi dan berinteraksi dengan budaya, sistem nilai, teknologi, dan aturan-aturan yang mengikat. Dalam melaksanakan aktivitas dakwah yang di dalamnya sarat dengan semangat nilai-nilai spiritual yang humanis, tidak bisa dipungkiri diperlukan suatu pendekatan, dibarengi dengan strategi yang diperhitungkan dengan matang dan relevan agar dakwah mudah diterima oleh masyarakat, kegiatannya berlangsung efektif dan tujuan yang dinginkan dapat tercapai dengan baik.

Strategi dakwah artinya metode, siasat, taktik atau manuver yang dipergunakan dalam aktivitas (kegiatan) dakwah. ${ }^{38}$ Strategi dakwah yang digunakan dalam usaha dakwah haruslah memperhatikan beberapa asas dakwah agar proses dakwah dapat mengena sasaran dan mudah diterima oleh masyarakat objek dakwah. Beberapa asas dakwah yang harus diperhatikan di antaranya adalah:

35 Anida, "Dakwah Kekinian tentang Masyarakat, Budaya Pop, Etnik dan Teknologi", (dalam Majalah Ilmiah. Aktualisasi Nuansa Ilmu Dakwah. Fakultas Dakwah IAIN Sunan Gunung Djati Bandung, Volume 6 Nomor 12/Januari 2004), 209.

36 Acep Aripudin dan Syukriadi Sambas, "Dakwah Damai: Pengantar Dakwah Antarbudaya", (Bandung: Remaja Rosdakarya, 2007), 58.

37 Samsul Munir Amin, "Rekontruksi Pemikiran Dakwah Islam", Jakarta: Amzah, 2008), 176.

38 Asmuni Syukir dalam Samsul Munir Amin, "Rekontruksi Pemikiran Dakwah Islam", (Jakarta: Amzah, 2008), 176. 
1) Asas filosofis: asas ini terutama membicarakan masalah yang erat hubungannya dengan tujuan-tujuan yang hendak dicapai dalam proses atau dalam aktivitas dakwah.

2) Asas kemampuan dan keahlian da'i: asas ini menyangkut pembahasan mengenai kemampuan dan profesionalisme da'i sebagai subjek dakwah.

3) Asas sosiologis: asas ini membahas masalah-masalah yang berkaitan dengan situasi dan kondisi sasaran dakwah. Misalnya politik pemerintah setempat, mayoritas agama di suatu daerah, filosofis sasaran dakwah, sosiokultural sasaran dakwah, dan sebagainya.

4) Asas psikologis: asas ini membahas masalah yang erat hubungannya dengan kejiwaan manusia. Seorang $d a^{\prime} i$ adalah manusia, begitupun sasaran dakwahnya yang memiliki karakter yang unik yakni berbeda satu sama lainnya. Pertimbangan-pertimbangan masalah psikologis harus diperhatikan dalam proses pelaksanaan dakwah.

5) Asas efektivitas dan efisiensi: asas ini maksudnya adalah di dalam aktivitas dakwah harus diusahakan keseimbangan antara biaya, waktu maupun tenaga yang dikeluarkan dengan pencapaian hasilnya, sehingga hasilnya bisa maksimal.

Dengan mempertimbangkan asas-asas sebagaimana tersebut di atas, seorang da'i tinggal memformulasikan dan menerapkan strategi dakwah yang sesuai dengan kondisi mad'u sebagai objek dakwah. ${ }^{39}$

\section{Prinsip-prinsip Komunikasi Dakwah}

Dakwah pada intinya adalah upaya mengajak dan atau mempengaruhi orang lain agar mereka mau mengikuti pesan-pesan dakwah yang disampaikan sang da'i. Agar aktivitas dakwah berjalan efektif, maka seorang da’i (sebagai komunikolog) harus mengetahui dan memahami prinsip-prinsip komunikasi efektif. Artinya, ketika melakukan komunikasi dakwah penekanannya pada muatan pesan yang disampaikan yaitu nilai-nilai ajaran agama, namun demikian prinsip-prinsip komunikasi yang berlangsung tetap sama.

Prinsip komunikasi efektif dapat berlangsung dengan baik apabila didukung oleh berbagai faktor, diantaranya adalah kita paham tentang prinsip-prinsip serta teknik berkomunikasi secara efektif. ${ }^{40}$ Berkenaan dengan prinsip-prinsip komunikasi dakwah, agar dakwah dapat efektif dan diterima masyarakat maka penting diperhatikan apa yang dikemukakan Faizah dan Effendi (2006), Suranto (2010) dan Muchtar (1996), sebagai berikut:

39 Samsul Munir Amin, "Rekontruksi Pemikiran Dakwah Islam", Jakarta: Amzah, 2008), 176-177.

40 Wahyu Ilaihi, "Dakwah Sebagai Solusi Perdamaian Global', (dalam Congress Proceeding. Fak. Dakwah IAIN Sunan Ampel Surabaya bekerjasama dengan APDI (Asosiasi Profesi Dakwah Islam Indonesia, 2009), 163. 
1) Prinsip Keteladanan.

Memulai dari diri sendiri (ibda' binafsik) dan keluarga merupakan hal penting yang harus dilakukan da'i. Al-Qur'an menegaskan: Qu anfusakum wa ablikum nara (QS. 66: 6). Komunikasi dakwah tentu mempunyai tujuan yang ingin dicapai, seperti menyampaikan informasi ajaran agama, bahkan mengubah sikap dan/atau perilaku jama'ah agar sesuai dengan nilai-nilai Islam. Untuk itu, keteladanan seorang da'i dan keluarganya menjadi penting, disamping merancang dan menerapkan strategi komunikasi yang relevan. Sorang da’i dituntut untuk menunjukkan keteladanan dalam segala aspek kehidupan, perkataan, perbuatan, dan tingkahlaku kepada umatnya, karena da'i akan menjadi panutan. Dalam kaitan ini, perlu disadari bahwa setiap kemuliaan selalu ada kewajiban yang menyertainya. Oleh karena itu, akblakul karimah yang didambakan oleh setiap muslim dan muslimah seharusnya tercermin melalui amal dan akhlak setiap pelaksana dakwah/da'i. Sebab dengan demikian dia tidak hanya menjadi penyebar ilmu pengetahuan dan agama, tapi sekaligus juga memberi teladan.

2) Prinsip Empati pada Pikiran dan Budaya Masyarakat.

Rasulullah menegaskan: Khatibinnas 'ala qadri 'uqulibim. Pesan dakwah harus disampaikan dengan menggunakan logika masyarakat, kemampuan berpikir mereka, mempertimbangkan budaya mereka, dan jika mungkin menggunakan bahasa mereka. Berkomunikasi dengan setiap orang/suatu masyarakat mensyaratkan satu pendekatan yang berbeda. Perbedaan latar belakang sosial budaya tidak dapat dihilangkan. Karakteristik masyarakat meliputi karakteristik sosial maupun budaya. Contoh karakteristik sosial, seperti jenis kelamin, tingkat pendidikan, latar belakang geografis, norma sosial, stratifikasi sosial, dan sebagainya. Sedangkan karakteristik budaya menyangkut nilai-nilai budaya yang dianut. Mengingat setiap orang memiliki latar belakang sosial budaya yang unik, berbeda dengan orang lain. Adanya perbedaan latar belakang budaya dapat menimbulkan kesulitan dalam berkomunikasi, karena terjadinya perbedaan penafsiran atau interpretasi atas pesan dan simbol yang digunakan dalam komunikasi itu. Apalagi dalam proses komunikasi dakwah. Karakteristik masyarakat merupakan informasi yang sangat berharga bagi da'i untuk dapat mengorganisasikan pesan dakwah yang relevan dengan karakteristik masyarakat tersebut.

3) Prinsip Sabar dan Tidak Berputus Asa.

Dalam menghadapi kesulitan dan tantangan, da'i harus bersabar, jangan bersedih apalagi berputus asa. Sudah menjadi sunnatullah bahwa setiap pembawa kebenaran pasti akan menghadapi berbagai tantangan. Seorang da'i hanya bisa mengajak, sedangkan yang memberi petunjuk adalah Allah SWT. 
4) Prinsip Proses dan Transaksi Informasi.

Komunikasi dakwah adalah suatu proses, karena komunikasi dakwah menunjukkan suasana aktif dan dinamis yang menggambarkan suatu proses yang senantiasa berkesinambungan. Proses tersebut merupakan proses yang disengaja, dengan demikian perlu direncanakan secara matang. Dalam komunikasi dakwah adanya komponen yang terlibat di dalamnya. Setiap komponen memiliki tugas atau karakter yang berbeda, namun saling mendukung terjadinya sebuah proses transaksi informasi yang dinamakan komunikasi dakwah. Dari proses komunikasi tersebut, yang ditransaksikan adalah pesan atau informasi kebenaran dari ajaran agama.

5) Prinsip Mediasi.

Dalam melakukan kegiatan komunikasi dakwah seorang da'i harus memposisikan dirinya sebagai mediator diantara berbagai golongan yang ada. Dengan kata lain, dalam kapasitasnya sebagai da'i dia berdiri di atas dan untuk semua golongan. Dalam kaitan ini, da'i harus mampu mendekatkan perbedaan yang muncul antar golongan, mencairkan perselisihan dan menyatukan yang berserakan, bukan sebaliknya membawa api dan mengobarkan perpecahan serta menyulut permusuhan. Dengan prinsip mediasi diharapkan umat Islam akan rukun dan harmonis dalam ridha dan bimbingan Allah.

6) Prinsip Kolektivitas dan Membangun Citra Positif.

Aktivitas dakwah yang dilakukan akan lebih bermakna apabila dilakukan secara terpadu dan terkoordinir secara kolektif dengan yang lain. Bila divisualisasikan di dalam profesi keilmuan dapat dianalogikan bahwa setiap bidang keahlian adalah penyempurnaan bidang keahlian yang lain. Karenanya, dalam prinsip kolektif menuntut adanya perencanaan untuk memungkinkan terjadinya kerjasama yang integral dan terpadu dari profesi, disiplin ilmu, dan keahlian. Inilah arah dakwah yang dimaksudkan. Namun demikian, penting diperhatikan citra positif dakwah karena akan berpengaruh pada kelancaran komunikasi dakwah itu sendiri. Citra positif bisa dibangun dengan kesungguhan dan konsistensi dalam waktu lama, tetapi citra buruk dapat terbangun seketika hanya oleh satu kesalahan fatal dari pelaku dakwah.

7) Prinsip Pentingnya Saluran (channel) yang Relevan.

Ada beberapa saluran komunikasi, baik secara lisan maupun tertulis yang dapat digunakan untuk menyampaikan pesan dakwah. Memilih satu dari beberapa saluran komunikasi yang ada seharusnya tidak menjadi keputusan yang dilakukan sambil lalu, karena setiap saluran komunikasi mempunyai keuntungan sekaligus kerugian. 
8) Prinsip Kesatuan Visi dan Tujuan.

Aktivitas komunikasi dakwah mengandung dimensi risalah, dimensi rahmah, dan dimensi kesejarahan. Ketiga dimensi dimaksud mengarah kepada perubahan perilaku manusia baik pada tingkat individu maupun kelompok ke arah perilaku yang makin Islami dan bermoral. Oleh karena itu, seruan ke jalan Allah dalam melakukan kegiatan komunikasi dakwah harus mempunyai kesatuan visi dan tujuan yang integral dan terpadu.

9) Prinsip Pemukiman.

Untuk mencapai tujuan dakwah yang berdimensi risalah, rahmah, dan sejarah dalam rangka memelihara masyarakat yang sosialistis religius, disarankan agar pada setiap daerah pemukiman dan daerah industri tersedia sarana ibadah dan kegiatan pembinaan mental. Akan jauh lebih efektif lagi apabila tersedia da'i dari kalangan penghuni pemukiman itu sendiri.

10) Prinsip Memperhatikan Skala Prioritas.

Da'i harus memerhatikan skala prioritas atau tertib urutan pusat perhatian dakwah, yaitu prioritas pertama berdakwah sehubungan dengan hal-hal yang bersifat universal, yakni al khair (kebajikan), yad'una ila al khair baru kepada amar ma'ruf dan baru kemudian nabi munkar (QS. 3: 104). Al khair adalah kebaikan universal yang datangnya secara normatif dari Tuhan, seperti keadilan dan kejujuran, sedangkan al ma'ruf adalah sesuatu yang secara "sosial" dipandang sebagai kepantasan. Sangat tidak produktif berdakwah dengan ramai-ramai membakar tempat maksiat (nahi munkar), tetapi mereka sendiri tidak adil dan tidak jujur.

Prinsip-prinsip dan materi dakwah haruslah terlebih dulu diketahui dan dipahami serta diamalkan secara baik oleh seorang da'i, baru kemudian disampaikan kepada umat. Selain itu, hal yang juga penting untuk diperhatikan bagi seorang da'i adalah karakter, budaya, dan tingkat pengetahuan masyarakat, serta keikhlasan da'i dalam menyampaikan dakwah sehingga dakwah yang disampaikan dapat diterima dengan mudah dan dipahami dengan baik. Romli, ${ }^{41}$ menambahkan "komunikasi dakwah bukan saja harus baik dalam hal isi (content) atau pesan (the message, what), melainkan juga harus baik dalam hal cara (the way, how). Prinsip komunikasi Islam antara lain: benar, baik, amar ma'ruf nabi munkar, dan bersumberkan al-Qur'an dan hadits (ajaklah mereka ke jalan Tuhanmu dengan bijak; bicaralah yang baik atau diam; bicaralah sesuai dengan kadar intelektualitas mereka; dan katakanlah kepada mereka perkataan yang membekas pada jiwa mereka (QS. An Nisa' :63)".

41 Melalui: < http://www. sunangunungdjati.com/blog/?p=10075 > [16/10/2011]. 


\section{Kesimpulan}

Kesimpulan dari pemaparan di atas adalah sebagai berikut:

1. Modernisasi secara positif memberikan kemudahan bagi kehidupan manusia, namun tidak dapat dipungkiri telah melahirkan berbagai persoalan, seperti merosotnya nilai-nilai moral, sosial, maupun spiritual.

2. Gerakan dakwah yang aktual, faktual dan kontekstual serta efektif, efisien dan berkesinambungan tetap dibutuhkan sebagai penawar dan upaya memecahkan problema kekinian yang sedang dihadapi umat.

3. Dari kacamata psikologi dakwah, efektivitas dakwah dapat dilihat dari 5 unsur berikut:
a. Jika dakwah dapat memberikan pengertian kepada masyarakat (mad'u) tentang apa yang didakwahkan.
b. Jika masyarakat (mad'u) merasa terhibur oleh dakwah yang diterima.
c. Jika dakwah berhasil meningkatkan hubungan baik antara da'i dan masyarakatnya.
d. Jika dakwah dapat mengubah sikap masyarakat mad'u.
e. Jika dakwah berhasil memancing respon masyarakat berupa tindakan.

\section{Daftar Pustaka}

\section{Buku dan Jurnal:}

Aripudin, Acep dan Syukriadi Sambas. 2007. "Dakwah Damai: Pengantar Dakwah Antarbudaya”. Bandung: Remaja Rosdakarya.

Mubarok, Ahmad. 2008. "Psikologi Dakwah”. Cetakan keempat. Jakarta: Pustaka Firdaus.

Anida. 2004. "Dakwah Kekinian tentang Masyarakat, Budaya Pop, Etnik dan Teknologi”. Majalah Ilmiah. Aktualisasi Nuansa Ilmu Dakwah. Fakultas Dakwah IAIN Sunan Gunung Djati Bandung, Volume 6 Nomor 12/Januari 2004.

Syukir, Asmuni dalam Samsul Munir Amin. 2008. "Rekontruksi Pemikiran Dakwah Islam". Jakarta: Amzah.

Ali, Baharudin. "Prinsip-prinsip Dakwah Antarbudaya”. Jurnal Tabligh: Media Pengkajian Dakwah dan Komunikasi Islam, Fakultas Dakwah dan Komunikasi UIN Alauddin Makassar, Edisi XXV/Juni 2012.

Enjang AS. "Smart Dakwah: Proses Dakwah Sesuai dengan Aspek Psikologi Mad'u". Jurnal Ilmu Dakwah: Academic Journal for Homiletic Studies. Fakultas Dakwah UIN Sunan Gunung Djati Bandung, Vol. 4 No. 12/Juni-Desember 2008. 
Enjang dan Aliyudin. 2009. "Dasar-dasar Ilmu Dakwab”. Bandung: Widya Padjadjaran.

Izmuddin, Iiz. "Hukum dan Etika Dakwah". Jurnal Hukum Islam "Al-Hurriyah" P3M STAIN Sjech Djamil Jambek-Bukit Tinggi, V01. 10, No. 1, Januari Juni 2009.

Jurnal Ilmu Dakwah. Fakultas Dakwah UIN Sunan Gunung Djati Bandung, Vol. 3 No. 6/Juli-Desember 2005.

Jurnal Ilmu Dakwah. Fakultas Dakwah dan Komunikasi UIN Sunan Gunung Jati Bandung. Vol. 4. No. 11. Januari - Juni 2008.

Ghazali, M. Bahri. 1997. "Dakwah Komunikatif: Membangun Kerangka Dasar Ilmu Komunikasi Dakwah". Jakarta: Pedoman Ilmu Jaya.

Puteh, M. Jakfar. 2006. "Dakwah di Era Globalisasi: Strategi Menghadapi Perubahan Sosial”. Cetakan Ketiga. Yogyakarta: Ak. Group.

Faridl, Miftah. 2005. “Cahaya Ukhuwah”. Bandung: Ikhtiar Publishing.

Suparta, Munzier dan Harjani Hefni (ed.). 2006. "Metode Dakwah". Cetakan ke2. Jakarta: Kencana.

Rukmana D.W., Nana. 2002. "Masjid dan Dakwah: Merencanakan, Membangun dan Mengelola Masjid Mengemas Sbstansi Dakwah Upaya Pemecahan Krisis Moral dan Spiritual”. Jakarta: Almawardi Prima.

Mubarok, Ahmad. 2008. "Psikologi Dakwah". Cetakan keempat. Jakarta: Pustaka Firdaus.

Faizah dan Lalu Muchsin Effendi. 2006. "Psikologi Dakwah". Jakarta: Kencana.

Rosyidi. "Pemberdayaan Masyarakat Melalui Dakwah Aktif Partisipatif". Jurnal Pengembangan Masyarakat Islam "Komunitas", Lembaga Pengabdian kepada Masyarakat (LPM) IAIN Raden Intan Bandar Lampung, Vol. 27, No. 1, Juni 2009.

Amin, Samsul Munir. 2008. "Rekontruksi Pemikiran Dakwah Islam". Jakarta: Amzah.

Ilaihi, Wahyu. "Dakwah Sebagai Solusi Perdamaian Global'. Congress Proceeding Fak. Dakwah IAIN Sunan Ampel Surabaya bekerjasama dengan APDI/Asosiasi Profesi Dakwah Islam Indonesia, 2009). 
Attarmizi, Yoga Ad. dan M. Yajid Kalam. 1999. "KH. Moh. Ilyas Ruhiat: Ajengan Santun dari Cipasung”. Bandung: Remaja Rosdakarya.

Zainudin. "Dakwah Transformative: Studi tentang Amar Makmur Nabi Munkar dalam Surat Ali Imran Ayat 11)". Jurnal PMI. Vol. IV. Nomor 2, Maret 2007.

\section{Internet:}

Melalui: < http://id.wikipedia.org/wiki/Budaya $>$ [27/09/2011].

Melalui: < http://ishthesyndicate.blogspot.com/2013/06/psikologi-dakwahantar-budaya.html $>[04 / 10 / 2013]$.

Melalui: < http://kabarnetwordpress. com/2010/02/26/peran-mahasiswasebagai-dai-ditengah-umat/ > [7/10/2011]

Melalui: < http://makalah-ibnu.blogspot.com/2008/10/peran-psikologi-dalamproses-dakwah.html $>[04 / 10 / 2013]$.

Melalui: < http://www. sunangunungdjati.com/blog/?p=10075 > $[16 / 10 / 2011]$. 